\title{
Expression of Mast Cell Major Basic Protein in Oral Squamous Cell Carcinoma
}

\author{
Alkhabuli $\mathrm{J}^{1 *}$ and High $\mathrm{A}^{2}$ \\ ${ }^{1}$ Oral Biology department, RAK College of Dental Sciences, United Arab Emirates \\ ${ }^{2}$ Department of Histopathology, St James University Hospital, UK
}

\begin{abstract}
Role of mast cells and eosinophils in oral tumours is not yet well define. Good and poor outcomes have been associated with eosinophils and mast cell abundant oral tumours. Major basic protein is one of the principal and specific proteins present in eosinophils. It is implicated in many pathological conditions including allergic reactions, parasitic infections and activation and stimulation of cells to produce cytokines.
\end{abstract}

The protein was thought to be exclusively present in the eosinophil granules. However, a recent study revealed its presence in mast cells as well.

In this brief article, the authors confirm the presence of major basic protein in mast cells associated with oral squamous cell carcinoma.

This finding may doubts the validity of using anti-major basic protein as eosinophil specific. Furthermore, labelling eosinophils using anti-major basic protein antibodies as a marker would mistake mast cells as eosinophils.

More importantly, the finding will better aid in understanding some of the mysterious function of MC in tumours.

\section{Introduction}

Major basic protein (MBP) is one of the principal proteins in eosinophils (Eos). The protein is thought to be exclusively present in the crystalloid core of the eosinophil granules [1]. However, a protein, which is immunochemically analogous to MBP was detected in small quantities in basophils [2]. Basophils also express the pro-major basic protein-1 but not the mature Eos [3]. MBP is implicated in many pathological conditions including allergic reactions and parasitic infections, as well as activation and stimulation of cells to produce cytokines. Recently, Nakajima et al. [4] demonstrated presence of abundant MBP in mast cells (MCs) and ranked it $4^{\text {th }}$ in quantity among other proteins. Therefore, according to this finding, the use of (MBP) eosinophil-specific is probably invalid. Also, labelling Eos using anti$\mathrm{MBP}$ antibodies as a marker would probably mistake MCs as Eos.

\section{Aim of the study}

We thought of investigating this finding in $\mathrm{MC}$ abundant tumour tissues and find out whether the tissue associated MCs express MBP or not. This could assist us in better understanding some of the mysterious function of MCs in tumours.

\section{Materials and methods}

Serial sections from a case of frozen human oral squamous cell carcinoma (SCC) were prepared according to the standard method for indirect double immunofluorescence staining. MCs are of either tryptase or tryptase and chymase phenotypes. Therefore, anti-tryptase antibody was used as a MC marker. The sections were incubated with mouse raised, anti-MBP followed by rabbit raised, anti-tryptase monoclonal primary antibodies. The sections were then incubated with Fluorescein Fluoroisothiocyanate; FITC) conjugated mouse anti-MBP and tetramethylrhodamine-isothiocyanate (TRITC) conjugated Swine anti-rabbit secondary immunoglobulins. Fluorescence microscope equipped with digital camera connected to PC was used for viewing of the sections.

To verify presence of any Eos, serial sections from the same case were histochemically stained with carbol chromotrope (CC), a well know specific stain for Eos [5]. A case of eosinophilic granuloma was used as a positive control.

\section{Results}

The fluorescent photomicrographs (Figures 1-3) demonstrate presence of MBP in MCs of the SCC. Figure 1 shows FITC labelled MBP

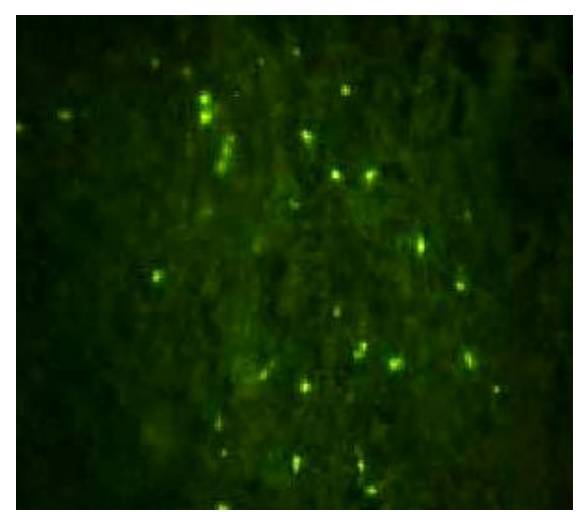

Figure 1: Demonstrates FITC-anti-MBP labelled mast cells (Original Mag $\mathrm{x} 200$ ).

*Corresponding author: Juma Alkhabuli, RAK College of Dental Sciences Associate Professor, Oral Biology department, Ras Alkhaimah, United Arab Emirates, Postal Box. 11172, Tel: 971502038545, E-mail: juma@rakmhsu.ac.ae

Received January 02, 2013; Accepted April 01, 2013; Published April 05, 2013

Citation: Alkhabuli J, High A (2013) Expression of Mast Cell Major Basic Protein in Oral Squamous Cell Carcinoma. J Cytol Histol 4: 170. doi:10.4172/21577099.1000170

Copyright: (c) 2013 Alkhabuli J, et al. This is an open-access article distributed under the terms of the Creative Commons Attribution License, which permits unrestricted use, distribution, and reproduction in any medium, provided the original author and source are credited. 
Citation: Alkhabuli J, High A (2013) Expression of Mast Cell Major Basic Protein in Oral Squamous Cell Carcinoma. J Cytol Histol 4: 170. doi:10.4172/2157-7099.1000170

(green spots), while Figure 2 demonstrates TRITC labelled tryptase (red spots). Figure 3 reveals colocalisation of the two proteins in the same cell (MC). Figure 4 shows no evidence of CC stain in the SCC section indicating absence of any eosinophils. Also, no extracellular staining of MBP was noticed in the SCC section (Figure 5).

\section{Discussion}

MBP has been reported in some MC type, though, it was speculated that the incorporation of free MBP in MCs was a result of endocytosis [6]. It is a well-known phenomenon that eosinophil becomes invisible after degranulation. Nakajima et al. [4], however detected abundant immunoreactive protein and mRNA of MBP in MC granules. Expression of This indicates that MC may undergo phenotypic changes and synthesize MBP. In the current study, no Eos was identified in the serial sections. Therefore, the MC associated MBP is constitutional and not a result of endocytosis. In addition, no free MBP was detected in the stroma. Recently, Plager et al. [7] discovered homolog of MBP, termed MBPH or simply, MBP2 and thought to be only present in Eos but not in other leukocytes. However, further investigations are awaited to confirm the finding. Although the mode of MBP cytotoxicity is unclear, the toxic effect on helminths and mammalian tissues is well documented [8-9], but its action on tumour cells has not yet been elucidated. The phenomenon of MC accumulation around tumour areas is a controversial subject and its significance is undecided.

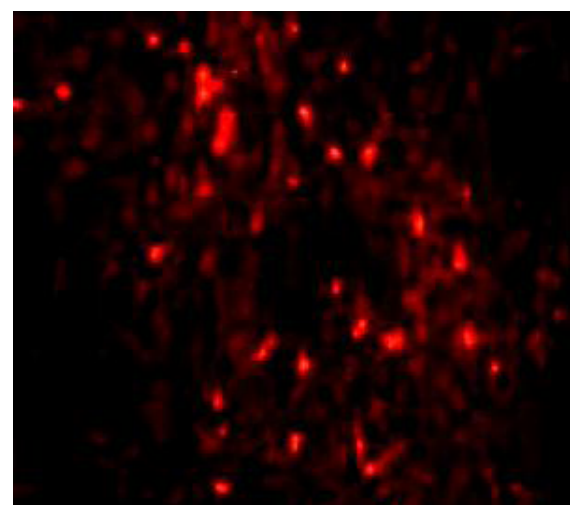

Figure 2: Demonstrates TRITC-anti-tryptase labelled mast cells (Original Mag $\mathrm{x} 200)$.

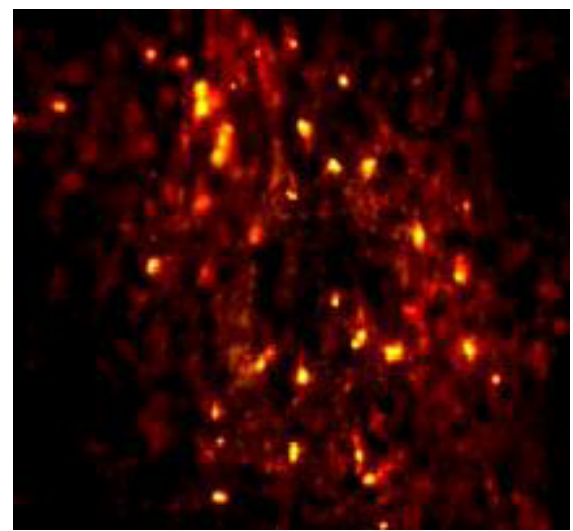

Figure 3: Demonstrates the co-localisation of the two proteins (Original Mag x200).

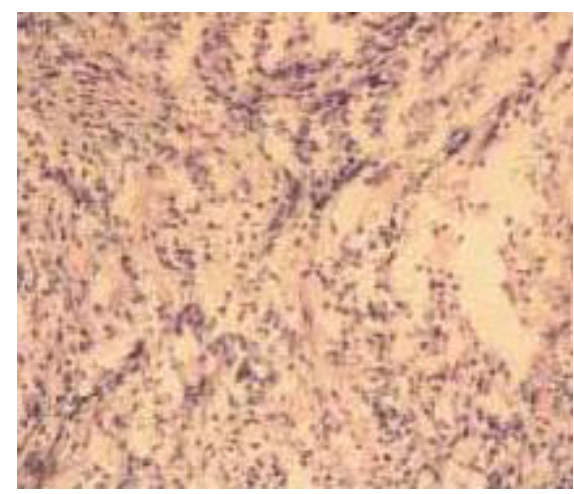

Figure 4: A serial section of frozen SCC stained with CC reveals presence of no eosinophils (Original Mag. x200).

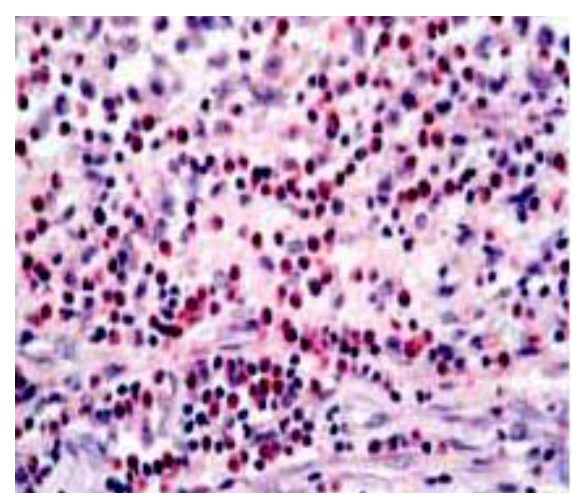

Figure 5: The control section stained with CC (Original Mag. x400 approx).

A considerable number of papers have recently addressed the potential role of mast cells in tumours with various outcomes. In literature, good and poor prognosis has been associated with high MC count in tumours [10-11]. In a previous study [12], we found that the 5 year survival was significantly lower in cases with low mast cell density ( $\mathrm{p}=0.006$, Kruskal-Wallis test). MC proteins, such as heparin, histamine, tryptase, and associated cytokines and growth factors have all been implicated in tumour promotion or inhibition [13]. Furthermore, cross-talk between mast cells and eosinophil in tumours has been suggested. Focal degranulation of mast cells, ultra-structural activation of eosinophil and apoptosis are among the noticed changes [14]. It appears that MC modulates itself depending on the type of tumour and stimulus of the stromal environment [15].

Many tissue changes including those associated with allergic reactions and tumours have been attributed to eosinophil contents. Nevertheless, with the presence of MBP in MCs we need to review role of immunosurveillance cells including eosinophil and MC in oral tumours.

\section{Conclusion}

This study confirms presence of MBP in MCs. Although this study is limited, the finding is crucial. It encourages us to further investigate this protein in a wider range of tumours to better understand its biological function in tumour associated MCs. Also, it demonstrates that the MBP is no more eosinophil-specific protein. 
Citation: Alkhabuli J, High A (2013) Expression of Mast Cell Major Basic Protein in Oral Squamous Cell Carcinoma. J Cytol Histol 4: 170. doi:10.4172/2157-7099.1000170

Page 3 of 3

\section{References}

1. Egesten A, Alumets J, Von Mecklenburg C, Palmegren M, Olsson I (1986) Localization of Eosinophil Cationic Protein, Major Basic Protein, and Eosinophilic Peroxidase in Human eosinophils by Immuno Electron Microscopic Technique. Journal of Histochemistry and Cyochemistry 34: 1399-1403.

2. Ackerman SJ, Kephart GM, Habermann TM, Greipp PR, Gleich GJ (1983) Localization of eosinophil granule major basic protein in human basophils. J Exp Med 158: 946-961.

3. Plager DA, Weiss EA, Kephart GM, Mocharla RM, Matsumoto R, et al. (2006) Identification of basophils by a mAb directed against pro-major basic protein 1 . J Allergy Clin Immunol 117: 626-634.

4. Nakajima T, Matsumoto K, Suto H, Tanaka K, Ebisawa M, et al. (2001) Gene expression screening of human mast cells and eosinophils using high-density oligonucleotide probe arrays: abundant expression of major basic protein in mast cells. Blood 98: 1127-1134.

5. Lendrum AC (1944) The staining of eosinophil, polymorphs and enteromaffin cells in histological sections. J Path. Bact 56:441.

6. Butterfield JH, Weiler D, Peterson EA, Gleich GJ, Leiferman KM (1990) Sequestration of eosinophil major basic protein in human mast cells. Lab Invest 62: $77-86$

7. Plager DA, Loegering DA, Checkel JL, Tang J, Kephart GM, et al. (2006) Majo basic protein homolog (MBP2): a specific human eosinophil marker. J Immunol 177: 7340-7345.
8. Filley WV, Holley KE, Kephart GM, Gleich GJ (1982) Identification by immunofluorescence of eosinophil granule major basic protein in lung tissues of patients with bronchial asthma. Lancet 2: 11-16.

9. Kierszenbaum F, Ackerman SJ, Gleich GJ (1981) Destruction of bloodstream forms of Trypanosoma cruzi by eosinophil granule major basic protein. Am J Trop Med Hyg 30: 775-779.

10. Tan SY, Fan Y, Luo HS, Shen ZX, Guo Y, et al. (2005) Prognostic significance of cell infiltrations of immunosurveillance in colorectal cancer. World $\mathrm{J}$ Gastroenterol 11: 1210-1214.

11. Rojas IG, Spencer ML, Martínez A, Maurelia MA, Rudolph MI (2005) Characterization of mast cell subpopulations in lip cancer. J Oral Pathol Med 34: 268-273.

12. Alkhabuli JO (2007) Significance of neo-angiogenesis and immuno-surveillance cells in squamous cell carcinoma of the tongue. Libyan J Med 2: 30-39.

13. Theoharides TC, Conti $P$ (2004) Mast cells: the Jekyll and Hyde of tumor growth. Trends Immunol 25: 235-241.

14. Caruso RA, Fedele F, Zuccalà V, Fracassi MG, Venuti A (2007) Mast cell and eosinophil interaction in gastric carcinomas: ultrastructural observations. Anticancer Res 27: 391-394.

15. Ozdemir O (2005) Immunosurveillance function of human mast cell? World Gastroenterol 11: 7054-7056. 